\title{
Early Detection of Neuroendocrine Prostate Cancer as Lineage Plasticity in Recurrent Prostate Cancer After Radiation and Androgen Deprivation Therapy: A Case Report
}

\section{Case Report}

Keywords:

Posted Date: January 4th, 2021

DOl: https://doi.org/10.21203/rs.3.rs-99714/v2

License: (1) This work is licensed under a Creative Commons Attribution 4.0 International License. Read Full License 


\section{Abstract}

The authors have requested that this preprint be withdrawn due to erroneous posting.

\section{Full Text}

The authors have withdrawn this preprint from Research Square. 